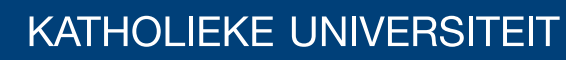 \\ LEUVEN
}

\section{Faculty of Business and Economics}

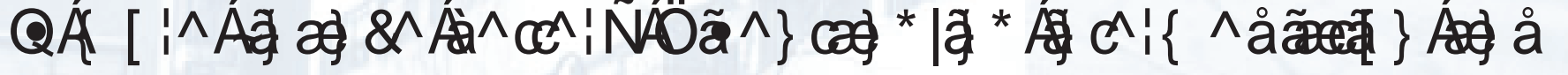
V] HHIHFWRIILQDQFDOK WAP V

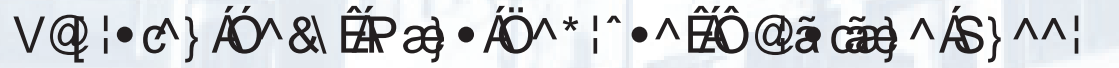

DEPARTMENT OF ACCOUNTANCY, FINANCE AND INSURANCE (AFI) 


\title{
Is more finance better? Disentangling intermediation and size effects of financial systems
}

\author{
Thorsten Beck \\ CentER, EBC, Tilburg University and CEPR \\ PO Box 90153, NL 5000 LE Tilburg, The Netherlands \\ E-mail: t.beck@uvt.nl \\ Hans Degryse \\ KU Leuven, Tilburg University and CEPR \\ Naamsestraat 69, BE-3000 Leuven Belgium \\ E-mail: hans.degryse@kuleuven.be \\ and \\ Christiane Kneer \\ CentER, EBC, Tilburg University \\ PO Box 90153, NL 5000 LE Tilburg, The Netherlands \\ E-mail: ekneer@uvt.nl
}

\begin{abstract}
Financial systems all over the world have grown dramatically over recent decades. But is more finance necessarily better? And what concept of finance - the size of the financial sector, including both intermediation and other auxiliary "non-intermediation" activities, or a focus on traditional intermediation activity - is relevant for its impact on real sector outcomes? This paper assesses the relationship between the size of the financial system and the degree of intermediation, on the one hand, and GDP per capita growth and growth volatility, on the other hand. Based on a sample of 77 countries for the period 1980-2007, we find that intermediation activities increase growth and reduce volatility in the long run. An expansion of the financial sectors along other dimensions has no long-run effect on real sector outcomes. Over shorter time horizons a large financial sector stimulates growth at the cost of higher volatility in high-income countries. Intermediation activities stabilize the economy in the medium run especially in low-income countries.
\end{abstract}

*We would like to thank Arnoud Boot and participants at the NAKE 2011 research day and the Prebem 2011 conference. 


\section{Introduction}

Financial systems all over the world have grown tremendously over the decade leading up to the Global Financial Crisis of 2008/9, both in absolute terms and relative to the size of the real sector. Financial sectors are largest in advanced countries but financial systems in developing countries have been catching up. Especially offshore financial centers have developed large financial sectors relative to the size of their underlying economies. The growth of the financial industry has long been considered a positive development by academics and regulators and has been facilitated by policies of financial liberalization. But is more finance necessarily better? And what concept of finance - intermediation activities, or the size of the financial sector, including both intermediation and other auxiliary "non-intermediation" activities- is relevant for real sector outcomes?

This paper assesses the relationship between the size of the financial system and the degree of intermediation, on the one hand, and GDP per capita growth and growth volatility, on the other hand. We contrast the effect of financial sector size with that of financial intermediation, and analyze whether intermediation and other non-intermediation activities have differential effects on growth and volatility.

Our analysis is motivated by two different views of the role of finance in an economy: the financial system as facilitator for the rest of the economy versus the financial system as a growth sector in itself which also performs non-intermediation activities. The 'intermediation or financial facilitator view' emphasizes the importance of the financial sector in mobilizing funds for investment and contributing to an efficient allocation of resources across households and enterprises. ${ }^{1}$ In doing so the financial sector supports capital formation and productivity growth, and ultimately economic growth. It also encompasses additional, more or less public services such as providing access to basic payment and transaction services that are important for the participation of the whole population in a modern market economy. The 'intermediation or financial facilitator view' thus highlights the role of the financial sector in facilitating the proper functioning of the modern market economy specifically in serving the other - non-financial - sectors of the economy. This view implies that the financial sector and the economy somehow develop in sync; i.e. the size of the financial sector adjusts to the

\footnotetext{
${ }^{1}$ See Levine (2005) and Merton (1995) for a discussion of the different functions of financial institutions and markets in a modern market economy and the channels through which they can foster economic development.
} 
economy at large. We would expect that the contribution of the financial sector to GDP develops with certain regularity, as the economy develops.

A very different view is one that focuses on financial services as a growth sector in itself, therefore also performing many to-the-home-country non-intermediation services. This view towards the financial sector often also sees it as an export sector, i.e. one that seeks to build a nationally centered financial center stronghold based on relative comparative advantages such as skill base, favorable regulatory policies, subsidies, etc. Economic benefits also include important spin-offs coming from professional services (legal, accounting, consulting, etc.) that tend to cluster around a financial center. We refer to this focus on financial services as a business in itself as the 'financial center view' encompassing intermediation but also non-intermediation activities.

The belief that a big financial system is beautiful has been reconsidered against the backdrop of the Global Financial Crisis of 2008/9 and the sharp output declines brought about by this event. Representatives of financial authorities in advanced countries have voiced their concern regarding the excessive size of the financial sector and called for regulatory restrictions (see e.g. Turner, 2010; Smaghi, 2010 and Trichet, 2010). It has been claimed that an oversized financial sector could result in misallocation of resources and instability. Imperfect competition and rent extraction (Bolton, Santos and Scheinkman, 2011; Cahuc and Challe, 2009), implicit insurance due to bailouts (Arcand et al., 2011), and negative externalities from auxiliary financial services which may be useful for some clients but not for society as a whole may lead the financial sector to grow too large relative to its 'social optimum' ${ }^{2}$

Recent empirical research has also embraced the idea that there might be limits to the benefits of finance. This literature focuses on financial intermediation and tests for nonlinearities in the finance-growth relationship (Rioja and Valev, 2004; Shen and Lee, 2006; Favara, 2003; Arcand et al., 2011; Cecchetti and Kharroubi, 2012). It neglects however that at least in advanced countries, the financial sector has gradually extended its scope beyond the traditional activity of intermediation between providers and users of funds towards nonintermediation financial activities. The importance of traditional financial intermediation relative to these non-intermediation financial activities has declined over time as financial

\footnotetext{
${ }^{2}$ An example of financial services which only benefits clients is the restructuring of firm finance to reduce tax payments.
} 
institutions have diversified into non-lending activities (Demirgüc-Kunt and Huizinga, 2010; Baele et al., 2007). Financial institutions have focused increasingly on proprietary trading, market making, provision of advisory services, insurance and other non-interest income generating activities. As a result, the traditional measures of intermediation activities have become less and less congruent with the reality of modern financial systems and recent papers are not very informative about the effect of financial sector size on growth and volatility. Given that non-intermediation activities may not exhibit the same profitability and stability as intermediation activities and given that they do not serve to perform the same functions as financial intermediation, it cannot a-priori be assumed that these activities have the same effect on growth or volatility.

In addition to its direct contribution to GDP (as a growth sector) and its indirect effects via the functions provided to the rest of the economy, the financial sector may affect growth through its impact on volatility. ${ }^{3}$ The different activities of the financial sector have different effects on volatility. Trading by financial institutions can for instance drive asset price bubbles. Rajan (2005) points out that the incentive structure of investment managers and intense competition lead investment managers to accept exposure to tail risks and to adopt herding behavior. These behaviors can reinforce each other in an asset price boom and drive prices away from fundamentals, creating the conditions for sharp realignment. Nonintermediation activities of the financial sector may, however, also dampen fluctuations in economic activity to the extent that they reduce agency problems and asymmetric information which amplify shocks to the real economy (Bernanke and Gertler, 1989). Intermediation may reduce volatility by alleviating firms' cash constraints (Caballero and Krishnamurty, 2001), by reducing the dependence of financial contracts on borrowers' net worth (Aghion et al., 1999) and through its effect on the cyclical composition of investment (Aghion et al., 2010). Financial deepening can also promote diversification which in turn reduces risk and dampens cyclical fluctuations (Acemoglu and Zilibotti, 1997). Aizenmann and Powell (2003) also suggest that costly intermediation multiplies initial increases in volatility. Financial

\footnotetext{
${ }^{3}$ Theory suggests that volatility affects growth but predictions about the sign of this effect are ambiguous. In the presence of diminishing returns to investment endogenous growth models predict a negative relationship between business cycle volatility and growth. The opposite holds if precautionary savings, creative destruction, liquidity constraints or high-return high-risk technologies are taken into account (Imbs, 2007). The empirical literature has documented a negative correlation of growth and volatility at the country level (Ramey and Ramey, 1995). In our sample we find a negative or zero correlation depending on the time horizon considered.
} 
intermediation could, however, also increase volatility by increasing leverage, thus making firms more vulnerable to shocks (Kaminsky and Schmukler, 2008).

This paper aims to shed light on several issues. First, we document trends in the financial industry over the recent past. We show that the size of the financial sector has increased dramatically in both advanced and emerging market economies. We also document the high volatility of the financial sector relative to the economy as a whole. Second, we analyze whether this increase in size has been beneficial for the real economy. We assess how variation in financial sector size is associated with growth and volatility, employing different proxies for financial sector size from different data sources - the share of the financial sector in total value added, employment, working hours and total compensation. Third, we try to disentangle the size versus intermediation effects on growth and volatility. We do this by including size in the regression model while controlling for intermediation. In this way we study the association of non-intermediation with growth and volatility as ceteris paribus any increase in size then comes from non-intermediation activities. Finally, we investigate whether the relationships of financial sector size, intermediation and non-intermediation with growth and volatility differ across time periods and countries' income levels.

In line with previous research, we find that over the long run financial intermediation is positively associated with growth and negatively with growth volatility. Both effects have however become weaker over time. The overall size of the financial sector does not seem to be associated with long-run growth or volatility once we control for intermediation, suggesting that non-intermediation activities are not associated with long-run growth or volatility. Our analysis also shows that neither the size of the financial sector nor intermediation is related with growth over the medium run, i.e. over five-year periods. This result obtains despite a positive growth effect of the size of the financial sector in the subsample of advanced countries when intermediation is controlled for. In the medium run, intermediation and non-intermediation services have opposing associations with volatility. Intermediation stabilizes the economy - a finding largely driven by the low-income countries in our sample -, while non-intermediation services increase volatility - a finding mainly driven by the high-income countries.

Overall, our results suggest that the financial sector size and the associated intermediation and non-intermediation services play very different roles depending on the state of development of a country. In developing countries, shock absorption via credit extension seems to be an important function of the financial sector. An expansion of the 
financial sector along dimensions other than intermediation does not seem to result in either higher growth or lower volatility. In advanced countries, an expansion of non-intermediation services and the related increase in overall financial sector size increases growth but comes at the cost of higher volatility. Increased intermediation activity by contrast has no effect on our outcome variables in the medium-term though it is associated with higher growth over a longterm horizon.

We build on a large body of research which focuses on the relationship between financial development and economic growth (King and Levine, 1993; Levine and Zervos, 1998; Rajan and Zingales, 1998; Beck et al., 2000; Beck and Levine; 2004). Levine (2005) provides an overview of this literature. Financial development is usually measured by the level of credit as a share of GDP and an indicator of stock market activity. The general conclusion which emerges from the cross-country studies in this field is that financial sector deepening has a large positive effect on economic growth. More recently, research has focused on the link between financial depth and volatility. The findings depend on the specific sample and estimation methodology used. While some studies suggest that a more developed financial system is associated with reduced growth volatility (Easterly et al., 2000; Denizer et al., 2002; Raddatz, 2006), others find no robust relationship between these variables (Beck et al., 2006).

A related strand of literature has explored whether there are limits to the benefits of financial development. These studies detect nonlinearities in the relationship between financial development and economic growth. Although there is no consensus on the precise functional form of this relationship, most of the papers conclude that the impact of finance on growth is smaller at higher levels of financial development. The evidence provided by Masten et al. (2007) suggests that financial development has the largest effect on growth in countries with a level of financial development below some threshold, while the effect is found to be close to zero above the threshold. Shen and Lee (2006) suggest that the relationship between growth and financial development is best described by an inverse U-shape, while Favara (2003) finds that growth is an S-shaped function of financial development. Rioja and Valev (2004) find that financial development significantly promotes growth in countries with intermediate levels of financial development. Aghion et al. (2005) argue that the reason for the non-linearity of the finance-growth relationship might be that financial development helps catch up to the productivity frontier, but has limited or no growth effect for countries that are close or at the frontier. One reason for these non-linearities might be the beneficiary of the 
credit as argued by Beck et al. (2012) who explore the differential growth effects of enterprise and household credit. Consistent with theory they find that the growth effect of financial deepening comes through enterprise rather than household credit. Most of the financial deepening in high-income countries has come through additional household lending, which thus might explain the insignificant finance-growth relationship across high-income countries.

The difference between our paper and previous research is that our analysis focuses on the impact of the size of the financial sector on economic growth or volatility rather than on the effect of the level of financial intermediation. We share the skepticism that more finance is necessarily better with the literature on nonlinearities. In contrast to this literature however, we test whether potential nonlinearities arise because financial institutions change their mix of activities as the financial sector expands. More specifically, our paper attempts to discriminate between the impact of intermediation and non-intermediation activities provided by the financial sector, while the empirical studies mentioned above mostly rely on measures of the size of credit markets to gauge the level of financial development. In our empirical analysis these indicators serve to capture the extent to which the financial industry performs its function as an intermediary between borrowers and lenders.

Our paper also relates to the few studies which investigate the expansion of the financial sector without focusing specifically on its growth impact. Philippon (2008) attempts to explain the rise of the financial sector share in US GDP over the postwar period using both theory and evidence. He argues that this evolution has mainly been driven by corporate demand. Haldane et al. (2010) document the extraordinary growth of the financial industry in the UK since the 1970s as reflected in real value added data, gross operating surpluses and returns on equity of financial institutions. The authors show that over much of the period, this trend has also been accompanied by increases in the share of resources absorbed by the financial sector. Turner (2010) focuses on the expansion of different elements of the UK financial sector and sheds light on changes in the mix of activities performed by this sector and argues that some of the activities that the financial sector has recently embraced do not provide any economic value and are not welfare enhancing.

Finally, our paper relates to bank-level evidence on the relationship between shifts towards fee-generating activities and banks' performance/risk profiles. Most papers focus on the US (e.g. Demsetz and Strahan, 1997; Stiroh, 2004; Stiroh and Rumble, 2006) but more recently, international evidence has emerged (e.g. Baele et al., 2007; Laeven and Levine, 2007; Demirgüc-Kunt and Huizinga, 2010). These studies typically come to the conclusion 
that diversification into fee-generating activities comes at the cost of increased volatility. The evidence on the effect of increased exposure to volatile non-lending activities on risk-adjusted performance measures is mixed.

Before proceeding, several caveats are called for. First, as this is an initial exploration of the differential relationships between intermediation and non-intermediation financial activities, on the one hand, and growth and volatility, on the other hand, we focus on OLS regressions, leaving issues of endogeneity and omitted variable biases for future research. ${ }^{4}$ Second, our proxy for financial sector size is a crude indicator focusing on the financial system's contribution to the economy, rather than reflecting the broader concept of its sociopolitical importance. In spite of these shortcomings, we still think that our findings are insightful and policy-relevant.

The remainder of the paper is organized as follows. Section 2 introduces the dataset. Our empirical methodology is presented in Section 3. Sections 4 and 5 discuss our results for our main indicator of financial sector size and alternative indicators stemming from an alternative data source. Section 6 concludes.

\section{Data}

The sample employed in the first part of our analysis consists of 77 countries with data for the period 1980 to $2007 .^{5}$ Although the potential instability associated with a large financial sector is central to our argument, we exclude the recent crisis from the sample period in order to be able to draw more general conclusions. Given the sudden large output declines which are reflected in the data as from 2008, results would be dominated by this event. Our sample period nevertheless covers several crisis episodes such as the Latin American crises of the 1980s, the East Asian currency crisis of 1997 and the Scandinavian banking crises in the 1990s. Table 1 provides a list of the included countries. There is a wide variation in the size of the financial system across our sample countries. Our list includes a number of countries which are usually classified as financial centers, for example the UK, the US, Luxembourg,

\footnotetext{
${ }^{4}$ Unlike in the case of financial development, where a strong literature has emerged linking cross-country differences in financial development to legal traditions of countries, there is no comparable literature yet on the exogenous determinants of financial system size.

${ }^{5}$ Only countries with at least five observations over the sample period are included. Outliers were removed.
} 
Ireland, Japan, Hong-Kong or Switzerland, or offshore financial centers such as Mauritius, Panama or Uruguay (see e.g. the classification of the IMF, 2000).

To gauge the size of financial systems, we use the value added share of the financial sector in GDP from the national accounts tables of the United Nations Statistics Division (UNSD). ${ }^{6}$ Gross value added equals output minus intermediate consumption valued at basic prices. We base our size measure on sector $\mathbf{J}$ of ISIC, which is composed of financial intermediation, insurance funding, pension funding and activities auxiliary to financial intermediation. This includes traditional intermediation services such as loan provision to businesses and consumers, but also investment in securities for own account and on behalf of others as well as advisory services. This broad definition of the financial sector implies that our gross value added measure gauges overall financial activity and encompasses both intermediation and non-intermediation activities. ${ }^{7}$

The data in Table 1 show that in most countries the financial industry makes up for a substantial part of the economy. Here we present the value added shares for the years 1995 and 2005. In Luxembourg, Switzerland and Zambia the share of finance in GDP exceeded $10 \%$ in 1995. Luxembourg's financial sector leads the list with a value added share of nearly one quarter. On the other extreme, the financial sector contributed less than two percent to total value added in Bangladesh, Iran, Niger and Rwanda in 1995. A comparison of the financial sector size in 1995 and 2005 shows that in the decade prior to the crisis the value added share of the financial sector has increased substantially in most countries: Out of the 38 countries for which we have data in both years, more than $70 \%$ saw an increase in the value added share of the financial sector. The growing importance of the financial sector is also reflected in the growth rates of real GDP and the financial industry. Columns 3 and 4 of Table 1 show average annual growth of gross value added generated by the financial sector and real GDP over the period from 1980 to 2007, respectively. We learn that the financial sector has outpaced economic growth in all but one country. The last two columns of Table 1 show the standard deviation of the growth of value added of the financial sector and real GDP growth.

\footnotetext{
${ }^{6}$ See the data appendix at the end of the paper for a detailed description of all variables and data sources.

${ }^{7}$ Other intuitive measures of financial sector size such as the shares of labor and capital input or returns to factors are not available for most of the countries in our sample and are therefore not explored in our first part. However, alternative indicators are available for a smaller sample of countries covered by the KLEMS database. We employ this second sample in section 5.
} 
A comparison of these figures reveals that the financial sector is considerably more volatile than the economy as a whole.

A direct breakdown of financial sector size into financial intermediation and other non-intermediation activities is not possible on the basis of this data source. We infer the effect of non-intermediation by including next to the size indicator also an indicator of intermediation into the regression specification. Ceteris paribus, a change in size keeping intermediation constant then measures the impact of the other non-intermediation activities. We use as measure of intermediation the natural logarithm of the ratio of credit to GDP from the financial structure database of the World Bank (Beck et al., 2010). More specifically, the variable intermediation is defined as the log of claims on the domestic private sector by deposit money banks as a share of GDP. This variable has been used by the finance and growth literature to gauge the impact of the financial intermediation on economic growth (Beck et al., 2000; Beck and Levine, 2004, among others).

As a preliminary step, we investigate how the size of the financial sector as measured by the value added share, size, is empirically correlated with intermediation. A regression of size on intermediation indicates that lending activities contribute substantially to the value added generated by the financial sector, with a coefficient of 1.6 significant at the $1 \%$ level. An increase in intermediation by one standard deviation increases the share of the financial sector in GDP by about 1.3 percentage points. ${ }^{8}$

Figures 1 to 3 show the developments of size and intermediation over time in the UK, Turkey and Mauritius. These three countries illustrate the potential divergence between size and intermediation and highlight the importance of going beyond traditional measures of financial development. In the UK, for instance, the financial sector shrank from $9 \%$ to $5 \%$ of GDP from 1985 to 1990 while lending activities grew substantially over the same period. In the second half of the 1990s the financial industry shrank by another percentage point but intermediation remained roughly constant. Only in the early 2000s did the UK financial system start to increase significantly in size. Turkey witnessed an increase in financial sector size over the sample period, which was not accompanied by an expansion of intermediation activities. However, this overall increase in financial system size was accompanied by a high

\footnotetext{
${ }^{8}$ We could proxy for non-intermediation financial services by employing the residuals of this regression. Such a decomposition, however, would lead to a coefficient on non-intermediation which is identical to the coefficient on size when including both intermediation and size in the regression explaining growth or volatility.
} 
volatility, possibly related to systemic distress the Turkish financial system experienced over this period. On the other hand, there are many countries like Mauritius in our sample where size and intermediation are both upward trending and move in par.

Summary statistics of the two financial indicators size and intermediation, and our dependent variables GDP per capita growth and growth volatility for the cross-sectional dataset are displayed in Table 2 Panel A. We also show summary statistics for nonintermediation which we proxy by the residuals stemming from our regression of size on intermediation. On average the financial industry accounts for about $5 \%$ of a country's GDP. The residuals measuring non-intermediation are dispersed around a mean of zero. The residual averages of Bangladesh, Senegal and Mali are smallest suggesting that the nonintermediation business is relatively insignificant in these countries. The opposite is the case in Luxembourg, Zambia and Switzerland where country averages are largest. Table 2 Panel B shows pairwise correlation coefficients. Both the intermediation and non-intermediation activities are positively correlated with financial sector size. Another interesting observation from the correlation tables is the absence of a long-run relationship between growth and volatility. Further investigations show, however, that this does not hold if growth rate averages and volatilities over shorter time windows are considered. The correlation coefficients for the 5-year windows in Table 3 Panel B show that in this case an increase in volatility is associated with lower growth rates.

\section{Methodology}

Our methodology involves two steps. We first investigate the relationship between either intermediation or financial sector size on the one hand and growth and volatility on the other hand:

$$
\begin{aligned}
& \text { Growth }_{\text {it }}=\alpha_{0}+\alpha_{2} \text { Intermediation }_{i t}+\alpha_{3} X_{i t}+\varepsilon_{i t} \\
& \text { Volatility }_{i t}=\beta_{0}+\beta_{2} \text { Intermediation }_{i t}+\beta_{3} X_{i t}+\varepsilon_{i t} \\
& \text { Growth }_{\text {it }}=\alpha_{0}+\alpha_{1} \text { Size }_{i t}+\alpha_{3} X_{i t}+\varepsilon_{i t} \\
& \text { Volatility }_{i t}=\beta_{0}+\beta_{1} \text { Size }_{i t}+\beta_{3} X_{i t}+\varepsilon_{i t}
\end{aligned}
$$


The dependent variables are GDP per capita growth (growth) and its standard deviation (volatility) in specifications (1) and (3), and (2) and (4), respectively. Growth is calculated as the annual difference in the logarithm of real GDP per capita and volatility is the standard deviation of the growth rate within each time period t for each country i. Intermediation equals $\ln$ (credit to GDP). Size is the value added share of the financial industry in GDP. $\mathrm{X}_{\mathrm{it}}$ is a vector of standard control variables consisting of the log of beginning-of-period real GDP per capita, average years of schooling of the population aged 25 and above, and a policy variable. As a policy variable we include either inflation, government expenditures to GDP or trade openness as measured by the ratio of exports plus imports to GDP. ${ }^{9}$

We estimate this regression for two different datasets. First, we use a cross-sectional dataset in order to capture long-term relationships between the variables in question. In this case, the data are averaged over the entire sample period for each country and volatility is calculated as the standard deviation of the growth rate of per capita GDP between1980 and 2007. Second, we construct a panel dataset where data were averaged over non-overlapping 5year windows (i.e. 1980-1984, 1985-1989, 1990-1994, 1995-1999, 2000-2004 and 20052007). The volatility is calculated as the standard deviation of the growth rate for each of the six intervals. Using 5-year periods allows capturing relationships between the variables in the medium term. ${ }^{10}$

In a second step, we include both size and intermediation in the same regression to check whether a size effect persists once intermediation is controlled for. This allows us to infer the effect of non-intermediation. Ceteris paribus, a change in size keeping intermediation constant measures the impact of a change in the auxiliary non-intermediation activities. This leads us to estimate the following specifications:

$$
\begin{aligned}
& \text { Growth }_{\mathrm{it}}=\alpha_{0}+\alpha_{1} \text { Size }_{\mathrm{it}}+\alpha_{2} \text { Intermediation }_{\mathrm{it}}+\alpha_{3} \mathrm{X}_{\mathrm{it}}+\varepsilon_{\mathrm{it}} \\
& \text { Volatility }_{\mathrm{it}}=\beta_{0}+\beta_{1} \text { Size }_{\mathrm{it}}+\beta_{2} \text { Intermediation }_{\mathrm{it}}+\beta_{3} \mathrm{X}_{\mathrm{it}}+\varepsilon_{\mathrm{it}}
\end{aligned}
$$

\footnotetext{
${ }^{9}$ A similar set of control variables has been used by Beck et al. (2000) and Beck and Levine (2004).

${ }^{10}$ This approach is similar to Beck, Levine and Loayza (2000) who also use averages over 35 years (1960 to 1995 ) and five-year periods to gauge the relationship between finance and growth.
} 


\section{Size vs. intermediation - main results}

In this section, we present the results employing value added share as indicator of the size of the financial sector. The first subsection discusses our findings using the entire sample, i.e. all countries and the entire 1980-2007 period. In the second subsection, we investigate whether the results hold in the sub-period 1995-2007, while the third subsection looks at high versus low-income countries. Other indicators of financial size are available in the KLEMS dataset, which contains fewer countries. Results based on this dataset are presented in Section 5.

\subsection{Results for the period 1980-2007}

The results in Table 4 show a positive (negative) and significant long-run relationship between intermediation and growth (volatility). Panel A displays the results from OLS estimations of equations (1) and (2) using cross-sectional data, averaged over the period 1980 to 2007. For each dependent variable, the three columns provide the outcomes for a different set of controls. The results suggest that there is a positive long-run relationship between intermediation and growth. An increase in intermediation by one standard deviation (0.78) is associated with an increase in annual real GPD per capita growth by 0.6 percentage points, which compares to a mean growth rate of 1.7 percent and a standard deviation of 1.4 percent over the 1980 to 2007 sample period. Furthermore, higher levels of intermediation are associated with lower volatility as can be seen from the last three columns in Table 4 Panel A. In particular, a one standard deviation increase in intermediation is associated with a decrease in volatility by around 0.8 percentage points, compared to an average volatility of 3.5 percent. Table 4 Panel B presents the results from OLS estimations using the 5-year window nonoverlapping panel data. The results indicate that intermediation is positively but not significantly associated with growth over a five-year horizon, but significantly and negatively with volatility, though with somewhat smaller coefficient sizes. Turning to the control variables, we find evidence for a convergence effect in the growth regressions, as lagged GDP per capita enters negatively and significantly, and evidence for a positive relationship between education and growth. None of the other control variable enters significantly in a consistent manner across the cross-sectional and panel regressions.

The Table 5 results show a positive relationship between financial sector size and long-term growth. Panel A displays the results from OLS estimations of equations (3) and (4) 
using cross-sectional data. The results suggest that there is a positive long-run relationship between size and growth. An increase in the value added share of finance, size, by one standard deviation (3.1 percentage points) is associated with an increase of the growth rate by 0.4 percentage points. Surprisingly, we find that size is not significantly associated with variation in volatility. Table 5 Panel B presents the results from OLS estimations using panel data. The results indicate that financial sector size is not significantly associated with either growth or volatility over a five-year horizon.

The results in Table 6 show that once intermediation services are controlled for, financial sector size is no longer significantly associated with GDP per capita growth, but negatively with volatility over a medium-run horizon. Panel A shows the results for the crosssectional sample using specifications (5) and (6). Ceteris paribus, a change in size keeping intermediation constant measures the association of a change in other non-intermediation activities with growth or volatility. The results in Panel A show that these non-intermediation activities are not significantly associated with GDP per capita growth or volatility. This suggests that the positive relationship between size and growth documented in Table 5 Panel $A$ is due to the positive effect of traditional intermediation activities provided by financial institutions. Panel B of Table 6 presents the results for the panel data sample. The results show that, over a five-year horizon, a larger financial sector size is not significantly associated with growth but positively and significantly with volatility. This suggests that, ceteris paribus, an increase in size which is not driven by intermediation activities is associated with more volatile growth. In line with previous research we find that credit provision as measured by intermediation boosts long-run growth and stabilizes the economy in both the medium and the long run. This suggests that the non-intermediation and the intermediation variable have opposite relationships with volatility, which may explain the absence of an association of size with volatility in Table 5 Panel B.

Summarizing, our evidence for the period 1980-2007 suggests that an expansion of the financial sector relative to the size of the rest of the economy has a positive relationship with long-run growth but not with growth rates in the medium run. This positive long-run association with growth seems to be driven by intermediation activities. Non-intermediation activities as identified by introducing size while controlling for intermediation do not seem to be associated with growth or volatility in the long term. In the medium run, neither financial sector size nor intermediation is associated with growth. We also find opposing effects of size and intermediation on volatility, with intermediation helping to dampen volatility, while non- 
intermediation services exacerbating it. These findings are partly in line with the facilitating view of the financial system, while they are not consistent with the financial center view.

\subsection{Results for the period $1995-2007$}

It has been argued that the strength of the finance-growth relationship exhibits important variations over time. Rousseau and Wachtel (2005, 2011), for example, find that the relationship has been weaker in recent decades. They argue that the role of the financial sector in absorbing shocks was more important in the 1970s and 1980s which were dominated by the oil shocks and episodes of high inflation in many countries. They also suggest that in some countries financial liberalization was not accompanied by the requisite development of lending expertise and regulatory skills, leading to credit booms and instability. Financial development might therefore not have generated the growth-benefits observed in earlier decades and might have played more of a role in increasing rather than reducing volatility. Furthermore, technological progress changed the nature and scale of non-intermediation activities over time, potentially leading to a different impact of size and intermediation on growth and volatility.

In order to assess whether the effect of size and intermediation has changed over time we repeat our estimations for a more recent period, the years 1995-2007. ${ }^{11}$ The cross-section evidence presented in Table 7 Panel A supports the claim that the finance-growth link has become weaker over time. ${ }^{12}$ Neither size nor intermediation is significantly associated with growth. The stabilizing effect of intermediation that was found for the earlier period is still present for the period 1995-2007. It is however weaker than for the entire period 1980-2007. The evidence for the panel data presented in table 7 Panel B suggests that the relationship between the financial variables and growth and volatility has not changed qualitatively over time. The volatility-reducing effect of intermediation is again slightly weaker for the more recent period. The volatility increasing impact of size, while controlling for intermediation, is

\footnotetext{
${ }^{11}$ We choose 1995 as the starting date in order to make results comparable to the evidence from the KLEMS database which is introduced in section 5 .

${ }^{12}$ For reasons of space we omit the regressions which include size and intermediation separately.
} 
slightly larger for the more recent period. In unreported regressions, we also repeat our estimations for the period 1980-1995 and find a positive and significant relationship between intermediation and growth, even when controlling for size.

Thus, the most fundamental change that we observe over time is the vanishing longrun effect of intermediation on growth from the mid-1990s onwards. This result might be related to the weakening of the stabilizing effect of intermediation as suggested by Rousseau and Wachtel $(2005,2011)$.

\subsection{Cross-country variation: high vs. low-income countries.}

Previous studies have also found that the effect of financial intermediation on growth differs systematically across advanced and developing countries. While some studies find that the beneficial effect of intermediation in strongest in middle-income countries (Rioja and Valev, 2004), others come to the conclusion that this effect is most pronounced in low and middleincome countries (De Gregorio and Guidotti, 1995). We therefore also explore the differential effects of intermediation and size on growth and volatility across countries at different income levels.

To test for systematic differences in the impact of our financial indicators we split our sample into low-income and high-income countries. Our high-income group includes the 27 countries in our sample that are classified by the World Bank as high-income or upper middle-income countries. The remaining 50 countries form the low-income group. Both groups include countries classified as financial centers. Due to the small number of observations in each income group we discard the cross-sectional estimations and focus exclusively on the panel estimations, i.e. the 5-year windows in our further analysis. We only show the results for specifications (5) and (6) where we include both size and intermediation as explanatory variables. Table 8, Panel A and B show the coefficients from separate regressions for the high-income and the low-income groups over the period 1980-2007, respectively.

The results in Table 8 suggest that neither size nor intermediation is significantly associated with GDP per capita growth in either high or low-income countries. The influence of our financial sector variables on volatility differs across the two income groups. In highincome countries, size is positively and significantly associated with volatility: keeping 
intermediation constant, an increase in size, probably stemming from non-intermediation activities, is associated with higher volatility in the high-income countries, while intermediation does not enter significantly in the regression of volatility in high-income countries. Intermediation, on the other hand, is significantly and negatively associated with volatility in low-income countries. Unlike in high-income countries, financial sector size is not significantly associated with volatility in low-income countries. Thus, the volatility increasing effect of size (and thus non-intermediation) that was found for the entire sample seems to be driven by high-income countries whereas the negative effect of intermediation on volatility is likely to be driven by low-income countries.

In the Appendix, Table A1, we also display the results for the period 1995-2007 for the two income groups. The results are similar to those for the period 1980-2007 with the important exception that size now has a positive effect on growth in the high-income countries.

In summary, we find that size while controlling for intermediation is associated with higher volatility only in the high-income countries and with higher growth only in the 19952007 period. Non-intermediation services might be more useful in high-income countries since there is more wealth which needs to be managed. A richer society might for instance demand more lifetime consumption-smoothing services. Furthermore, it has been argued that the sources of growth differ across developing and advanced countries. Acemoglu et al. (2002) show that advanced countries which are close to the technological frontier have an incentive to pursue a growth strategy based on innovation whereas developing countries which are further away from the technological frontier typically pursue a growth strategy based on capital accumulation. Traditional intermediation activities might be more suited to support capital accumulation whereas security dealing captured by our size measure controlling for intermediation might be more favorable to the funding of innovative activities (Allen, 1992). Furthermore, technological spillovers from the financial sector and especially non-intermediation services to the rest of the economy are more likely to occur in highincome countries which tend to specialize more in professional services. Close links between the financial sector and professional services might also explain the volatility increasing effect of size in high-income countries. Since the financial sector is inherently volatile and since the activity level of most other professional services is positively related to that of the financial sector, a larger financial sector with more non-intermediation activities might bring about higher growth volatility in high-income countries. The absence of a stabilizing effect of 
intermediation in high-income countries and the presence of such an effect in low-income countries might be due to a relatively more important role of the financial sector as a shock absorber in developing countries. In advanced countries, on the other hand, fiscal and monetary policy are used more effectively to stabilize the economy.

\section{Alternative indicators of financial sector size}

In section 4 we employed the value added share as a proxy for the size of the financial sector. This proxy is available for a large set of countries. In order to check the robustness of our results we repeat our analysis with the EU KLEMS database, which offers a variety of indicators for financial sector size for a subset of our previously employed sample. Specifically, in addition, to the size indicator we used so far, i.e. the value added share of the financial sector, we use three other indicators of financial sector size. The first is the compensation of employees in the financial sector divided by the sum of compensation across all industries (compensation share). The second indicator is the share of hours worked by the financial sector (share hours). Finally, we use the employment share of the financial sector (employment share).

The KLEMS database was originally constructed to analyze productivity in the European Union. Its country coverage is therefore limited to $25 \mathrm{EU}$ countries as well as Australia, Canada, Japan, South Korea and the United States which were included for comparison. We exclude Canada, Finland and Malta due to missing data. For the non-EU countries and the 14 old member countries data are available from 1970 onwards. As data on the 9 new EU member states start only in 1995 we limit our main analysis to the period 19952007. Furthermore, we focus on the panel dataset, i.e. 5-year windows, since our sample includes only 27 countries and present the results for equations (5) and (6) which include proxies for both financial sector size and intermediation.

The estimations using KLEMS data in Table 9 show that size while controlling for intermediation is positively and significantly associated with growth. This holds across all four indicators of financial sector size - value added share, compensation share, employment share and share hours. Controlling for intermediation, a larger financial sector size is also associated with higher growth volatility. This suggests that non-intermediation activities contribute to growth but also stimulate growth volatility. The evidence from the KLEMS 
dataset yields similar conclusions as the results for the high-income group based on the value added share (size) as reported in Section 4: size has a significant positive effect on both growth and volatility. This shows that our results do not depend on the specific size measure used in the main analysis. Consistent with our previous results on the sub-sample of highincome countries, intermediation does not enter significantly in any of the regressions.

Our findings on the importance of size are not only statistically but also economically significant. Varying with the size indicator and the control variables we include, a one standard-deviation increase in financial sector size is associated with 0.2 and 0.7 percentage points higher growth. However, a one standard increase in deviation in financial sector is also associated with a 0.3 to 0.5 percentage point higher volatility in growth. These estimates are in line with the ones reported above for the larger sample. As additional robustness tests, in the appendix (Table A2), we show the results when employing the period 1980-2007 for a smaller sample excluding transition countries. Our results are comparable to those reported above.

\section{Conclusion}

Is more finance necessarily better? And what concept of finance - financial center as measured by financial sector size or financial facilitator as measured by intermediation is relevant for real sector outcomes?

We document that the size of the financial sector has increased dramatically in both the developed and developing world in combination with a high volatility of the financial sector relative to the economy as a whole. In line with previous research we find that in the long run financial intermediation increases growth and reduces growth volatility. Both effects have, however, become weaker over time. The size of the financial sector while controlling for the level of intermediation in an economy does not seem to affect long-run growth or volatility. Our analysis also shows that neither the size of the financial sector nor intermediation is associated with higher growth in the medium run. This result obtains despite a positive growth effect of the size of the financial sector and the non-intermediation component in the subsample of high-income countries. Critically, financial system size, especially non-intermediation services, has a positive relationship with volatility in highincome countries over the medium-term. 
For shorter time horizons, we find differential volatility effects depending on the income level of countries. Intermediation and size have opposing effects on volatility. Intermediation stabilizes the economy, a finding which is largely driven by the low-income countries in our sample. A greater financial sector size stimulates growth volatility. This volatility enhancing effect of financial sector size is mainly driven by high-income countries.

All in all, our results suggest that a financial center role may stimulate growth at the cost of higher volatility for high-income countries. The financial facilitator function seems to help in stabilizing the economy in particular in low-income countries.

This paper offers initial and tentative evidence on the different roles that intermediation and non-intermediation activities play in the growth process of countries, as well as on the importance of different financial sector concepts. Future research will hopefully rely on more micro-level data and rigorous identification strategies to disentangle the effects of different financial services and financial system concepts. 


\section{References}

Acemoglu, D., Aghion, P. \& Zilibotti, F., 2002. Distance to Frontier, Selection, and Economic Growth. NBER Working Paper Series, No. 9066.

Acemoglu, D. \& Zilibotti, F., 1997. Was Prometheus unbound by chance? Risk diversification and growth. Journal of Political Economy, 105(4), p.709-751.

Aghion, P., Banerjee, A. \& Piketty, T., 1999. Dualism and Macroeconomic Volatility. Quarterly Journal of Economics, 114(4), p.1359-1397.

Aghion, P. et al., 2010. Volatility and growth: Credit constraints and the composition of investment. Journal of Monetary Economics, 57(3), p.246-265.

Aizenman, J. \& Powell, A., 2003. Volatility and Financial Intermediation. Journal of International Money and Finance, 22(5), p.657-679.

Allen, F. \& Gale, D., 1999. Diversity of Opinion and Financing of New Technologies. Journal of Financial Intermediation, 8(1-2), p.68-89.

Arcand, J.L., Berkes, E. \& Panizza, U., 2011. Too much finance?. Mimeo.

Baele, L., De Jonghe, O. \& Vandervennet, R., 2007. Does the stock market value bank diversification? Journal of Banking \& Finance, 31(7), p.1999-2023.

Beck, T., Demirgüç-Kunt A. \& Levine, R., 2000 Finance and the Sources of Growth, Journal of Financial Economics 58, 261-300.

Beck, T., Demirgüç-Kunt A. \& Levine, R., 2010. Financial Institutions and Markets Across Countries and Over Time: The Updated Financial Development and Structure Database. World Bank Economic Review 24, 77-92.

Beck, T. \& Levine, R., 2004. Stock markets , banks, and growth: Panel evidence. Journal of Banking \& Finance, 28(3), p.423-442.

Beck, T., Lundberg, M. \& Majnoni, G., 2006. Financial intermediary development and growth volatility: Do intermediaries dampen or magnify shocks? Journal of International Money and Finance, 25(7), p.1146-1167.

Beck, T.,Buyukkarabacak, B., Rioja, F. \& Valev,N., 2012 Who Gets the Credit? And Does it Matter? Household vs. Firm Lending Across Countries B.E. Journal of Macroeconomics: Contributions 12.

Bernanke, B. \& Gertler, M., 1989. Agency costs, net worth, and business fluctuations. American Economic Review, 79(1), p.14-31.

Bolton, P., Santos, T. \& Scheinkman, J.A., 2011. Cream skimming in financial markets. NBER Working Paper Series, No. 16804. 
Caballero, R. \& Krishnamurthy, A., 2001. International and domestic collateral constraints in a model of emerging market crises. Journal of Monetary Economics, 48(3), p.513-548.

Cahuc, P. \& Challe, E., 2009. Produce or speculate? Asset bubbles, occupational choice and efficiency. IZA Discussion Papers 4630.

Cecchetti, S.G. \& Kharroubi, E., 2012. Reassessing the Impact of Finance on Growth. BIS Working Paper Series, No. 381.

De Gregorio, J., 1995. Financial development and economic growth. World Development, 23(3), p.433-448.

Demirgüç-Kunt, A. \& Huizinga, H., 2010. Bank activity and funding strategies: The impact on risk and returns. Journal of Financial Economics, 98(3), p.626-650.

Demsetz, R.S. \& Strahan, P.E., 1997. Diversification , Size , and Risk at Bank Holding Companies. Journal of Money, Credit and Banking, 29(3), p.300-313.

Denizer, C.A., Iyigun, M.F. \& Owen, A., 2002. Finance and Macroeconomic Volatility. Contributions in Macroeconomics, 2(1).

Easterly, W., Stiglitz, Joseph E \& Stiglitz, J E, 2004. Shaken and Stirred: Explaining Growth Volatility, World Bank Publications.

Favara, G., 2003. An Empirical Reassessment of the Relationship between Finance and Growth. IMF Working Paper, WP/03/123.

Haldane, A., Simon B. \& Madouros, V., 2010. What is the contribution of the financial sector: Miracle or mirage?. In: The Future of Finance: The LSE Report.

Imbs, J., 2007. Growth and volatility. Journal of Monetary Economics, 54(7), p.1848-1862.

IMF, 2000. Offshore Financial Centers. IMF Background Paper June 23, 2000.

Kaminsky, G.L. \& Schmukler, S.L., 2008. Short-Run Pain, Long-Run Gain: Financial Liberalization and Stock Market Cycles. Review of Finance, 2008(2), p.1-40.

King, R.G. \& Levine, R., 1993. Finance and Growth: Schumpeter Might Be Right. Quarterly Journal of Economics, 108(3), p.717-737.

Kiyotaki, N. \& Moore, J., 1997. Credit Cycles. Journal of Political Economy, 105(2), p.211248.

Laeven, L. \& Levine, R., 2007. Is there a diversification discount in financial conglomerates? Journal of Financial Economics, 85(2), p.331-367.

Levine, R., 2005. Finance and Growth: Theory and Evidence. In: P. Aghion \& Durlauf, S., ed. 2005. Handbook of Economic Growth. Elsevier. Ch.12. 
Levine, R., Loayza, N. \& Beck, T., 2000. Financial intermediation and growth: Causality and causes. Journal of Monetary Economics, 46(1), p.31-77.

Levine, R. \& Zervos, S., 1998. Stock markets, banks, and economic growth. American Economic Review, 88(3), p.537-558.

Masten, A., Coricelli, F. \& Masten, I., 2008. Non-linear growth effects of financial development: Does financial integration matter? Journal of International Money and Finance, 27(2), p.295-313.

Merton, R.C., 1995. A Functional Perspective of Financial Intermediation. Financial Management, 24(2), p.23-41.

Philippon, T., 2007. Financiers vs. Engineers: Should the Financial Sector be Taxed or Subsidized?. Unpublished working paper.

Philippon, T., 2008. Why has the US financial sector grown so much? The role of corporate finance. NBER Working Paper Series, No. 13405.

Raddatz, C., 2006. Liquidity needs and vulnerability to financial underdevelopment. Journal of Financial Economics, 80(3), p.677-722.

Rajan, R.G., 2005. Has Financial Development Made the World Riskier?. NBER Working Paper, No. 11728.

Rajan, R.G. \& Zingales, L., 1998. Financial Dependence and Growth June 1998, 88(3), pp. 559-86. American Economic Review, 88(3), p.559-86.

Ramey, G. \& Ramey, V., 1995. Cross-country evidence on the link between volatility and growth. American Economic Review, 85(5), p.1138-1151.

Rioja, F. \& Valev, N., 2004. Does one size fit all?: a reexamination of the finance and growth relationship. Journal of Development Economics, 74(2), p.429-447.

Rousseau, P. L. \& Wachtel, P., 2005. Economic Growth and Financial Depth: Is the Relationship Extinct Already?. Working Papers DP2005/10, World Institute for Development Economic Research.

Rousseau, P.L. \& Wachtel, P., 2011. What Is Happening To the Impact of Financial Deepening on Economic Growth? Economic Inquiry, 49(1), p.276-288.

Shen, C.-H. \& Lee, C.-C., 2006. Same financial development yet different economic growth Why? Journal of Money, Credit and Banking, 38(7), p.1907-1944.

Smaghi, L. B., 2010. Has the financial sector grown too big?. Speech in Kypoto, 15 April 2010.

Stiroh, K.J., 2004. Diversification in Banking: Is Noninterest Income the Answer? Journal of Money, Credit and Banking, 36(5), p.853-882. 
Stiroh, K. \& Rumble, A., 2006. The dark side of diversification: The case of US financial holding companies. Journal of Banking \& Finance, 30(8), p.2131-2161.

Trichet, J.-C., 2010. What role for finance?. Lecture at Universidade Nova de Lisboa, Lisbon, 6 May 2010.

Turner, A., 2010. What do banks do? Why do credit booms and busts occur and what can public policy do about it?. In: The Future of Finance: The LSE Report 
Table 1 Size and volatility of the financial sector

\begin{tabular}{|c|c|c|c|c|c|c|}
\hline Country & $\begin{array}{l}\text { FS size } \\
1995\end{array}$ & $\begin{array}{l}\text { FS size } \\
2005\end{array}$ & $\begin{array}{l}\text { FS growth } \\
1980-2007\end{array}$ & $\begin{array}{l}\text { GDP growth } \\
1980-2007\end{array}$ & $\begin{array}{l}\text { SD } \\
\text { (FS growth) }\end{array}$ & $\begin{array}{l}\text { SD } \\
\text { (GDPgrowth) }\end{array}$ \\
\hline Albania & & 3.5 & 16.3 & 3.9 & 28.5 & 6.0 \\
\hline Algeria & 3.4 & & 12.8 & 2.7 & 24.8 & 2.5 \\
\hline Argentina & 3.8 & 4.0 & 11.3 & 2.4 & 14.3 & 6.6 \\
\hline Australia & 5.6 & 7.2 & 8.4 & 3.3 & 5.1 & 1.7 \\
\hline Austria & 6.4 & & 5.9 & 2.3 & 4.4 & 1.2 \\
\hline Bangladesh & 1.5 & 1.6 & 10.9 & 4.5 & 2.4 & 1.4 \\
\hline Belgium & 5.8 & 5.3 & 2.7 & 2.1 & 4.3 & 1.4 \\
\hline Belize & 5.5 & 8.1 & 13.7 & 5.7 & 15.6 & 4.8 \\
\hline Bolivia & 3.0 & 3.3 & 14.1 & 2.3 & 14.8 & 3.1 \\
\hline Botswana & 3.9 & 5.1 & 22.1 & 7.7 & 13.1 & 4.0 \\
\hline Brazil & 7.1 & 7.2 & 10.8 & 2.7 & 14.4 & 3.4 \\
\hline Bulgaria & 7.7 & 4.5 & 43.7 & 1.8 & 51.6 & 5.5 \\
\hline Cameroon & & 1.2 & -0.9 & 2.6 & 9.8 & 5.2 \\
\hline Canada & 6.2 & & 5.8 & 2.8 & 8.1 & 2.0 \\
\hline Colombia & 6.1 & 5.3 & 18.6 & 3.6 & 16.2 & 2.4 \\
\hline Costa Rica & 4.2 & 5.6 & 22.0 & 4.2 & 5.4 & 3.6 \\
\hline Cote d'Ivoire & 3.6 & & 15.0 & 0.8 & 10.8 & 3.7 \\
\hline Cyprus & 4.9 & 6.2 & 10.2 & 4.8 & 9.1 & 2.4 \\
\hline Denmark & 4.2 & & 6.9 & 2.1 & 10.4 & 1.7 \\
\hline Dom. Rep. & 2.8 & 3.9 & 23.0 & 4.7 & 8.9 & 4.0 \\
\hline Ecuador & 4.0 & 2.4 & 11.5 & 2.8 & 27.4 & 3.1 \\
\hline Egypt & & 8.1 & 7.8 & 5.0 & 13.4 & 2.1 \\
\hline El Salvador & 3.1 & 4.5 & 14.0 & 1.8 & 8.8 & 4.5 \\
\hline Estonia & & 3.2 & 18.3 & 1.8 & 13.5 & 7.3 \\
\hline France & 4.7 & & 7.3 & 2.1 & 7.9 & 1.1 \\
\hline Gambia & 8.2 & 6.3 & 5.9 & 3.9 & 4.2 & 2.9 \\
\hline Germany & 4.2 & 4.5 & 2.8 & 1.9 & 8.9 & 1.5 \\
\hline Greece & 3.9 & & 12.3 & 2.2 & 8.7 & 2.2 \\
\hline Guatemala & & 2.7 & 10.7 & 2.9 & 3.2 & 2.3 \\
\hline Guyana & 2.6 & 3.3 & 26.9 & 0.6 & 50.3 & 5.1 \\
\hline Honduras & & 5.2 & 15.7 & 3.4 & 5.3 & 2.6 \\
\hline Hong Kong & 9.3 & & 6.3 & 5.4 & 9.5 & 4.0 \\
\hline Hungary & 4.6 & & 12.9 & 1.7 & 7.1 & 3.5 \\
\hline Iceland & & 8.1 & 17.4 & 3.2 & 11.6 & 3.0 \\
\hline India & 5.6 & & 15.4 & 6.1 & 9.1 & 2.1 \\
\hline Indonesia & & 4.0 & 11.9 & 5.4 & 3.7 & 4.3 \\
\hline Iran & 0.8 & 3.6 & 45.6 & 3.2 & 36.8 & 6.5 \\
\hline Ireland & 4.6 & & 16.7 & 5.3 & 17.8 & 3.0 \\
\hline Italy & 4.2 & 4.3 & 7.6 & 1.8 & 7.5 & 1.2 \\
\hline Japan & 5.0 & & 4.3 & 2.4 & 6.4 & 1.9 \\
\hline Jordan & 3.4 & 6.4 & 12.7 & 5.0 & 16.3 & 5.8 \\
\hline Kenya & & 3.4 & 9.7 & 3.5 & 20.8 & 2.2 \\
\hline
\end{tabular}




\begin{tabular}{|c|c|c|c|c|c|c|}
\hline Country & $\begin{array}{l}\text { FS size } \\
1995\end{array}$ & $\begin{array}{l}\text { FS size } \\
2005\end{array}$ & $\begin{array}{l}\text { FS growth } \\
1980-2007\end{array}$ & $\begin{array}{l}\text { GDP growth } \\
1980-2007\end{array}$ & $\begin{array}{l}\text { SD } \\
\text { (FS growth) }\end{array}$ & $\begin{array}{l}\text { SD } \\
\text { (GDP growth) }\end{array}$ \\
\hline Korea, Rep. & 6.2 & 7.5 & 17.5 & 6.4 & 19.1 & 3.9 \\
\hline Latvia & 4.4 & 5.3 & 144.5 & 3.9 & 472.8 & 5.5 \\
\hline Lesotho & 3.3 & 4.9 & 18.0 & 3.5 & 18.1 & 3.2 \\
\hline Luxembourg & 24.7 & & 11.6 & 4.7 & 19.7 & 2.9 \\
\hline Malaysia & & 8.4 & 7.3 & 6.3 & 3.1 & 3.9 \\
\hline Mali & & 0.8 & 7.5 & 3.0 & 7.1 & 5.3 \\
\hline Mauritius & 5.7 & 9.0 & 16.1 & 5.2 & 7.4 & 1.6 \\
\hline Mexico & 6.1 & & 22.6 & 2.9 & 27.5 & 3.6 \\
\hline Morocco & & 5.1 & 8.0 & 3.7 & 6.7 & 4.8 \\
\hline Mozambique & 5.1 & 4.4 & 37.1 & 4.4 & 43.3 & 6.8 \\
\hline Nepal & & 3.4 & 19.1 & 4.3 & 12.2 & 2.8 \\
\hline Netherlands & 5.7 & 6.8 & 5.2 & 2.5 & 6.0 & 1.5 \\
\hline New Zealand & 5.3 & & 5.4 & 2.6 & 7.0 & 2.0 \\
\hline Niger & 1.5 & & 6.5 & 1.7 & 30.7 & 5.3 \\
\hline Norway & 3.8 & 3.5 & 8.8 & 3.0 & 12.8 & 1.6 \\
\hline Panama & & 8.7 & 6.8 & 3.9 & 6.0 & 4.9 \\
\hline Paraguay & 2.8 & 2.4 & 11.8 & 3.0 & 9.3 & 3.8 \\
\hline Peru & 2.5 & 3.0 & 22.3 & 2.7 & 24.1 & 6.1 \\
\hline Philippines & 4.1 & 4.8 & 13.8 & 3.2 & 5.7 & 3.6 \\
\hline Portugal & 5.5 & & 5.3 & 2.6 & 21.0 & 2.4 \\
\hline Romania & & 2.0 & 33.1 & 1.3 & 31.3 & 5.5 \\
\hline Rwanda & 1.9 & & 41.3 & 4.8 & 113.8 & 5.3 \\
\hline Senegal & & 1.1 & 10.0 & 3.0 & 21.0 & 3.1 \\
\hline South Africa & & 7.0 & 9.4 & 2.5 & 3.8 & 2.5 \\
\hline Spain & & 4.1 & 8.2 & 3.0 & 6.1 & 1.6 \\
\hline Swaziland & 3.5 & 2.7 & 9.0 & 5.4 & 7.6 & 4.4 \\
\hline Sweden & 3.8 & & 2.6 & 2.3 & 13.0 & 1.8 \\
\hline Switzerland & 10.3 & & 5.1 & 1.8 & 7.8 & 1.6 \\
\hline Thailand & 6.5 & 3.7 & 6.2 & 5.9 & 17.2 & 4.4 \\
\hline Turkey & 4.2 & 4.4 & 66.6 & 4.4 & 41.1 & 4.3 \\
\hline UK & 5.9 & 7.6 & 9.3 & 2.4 & 11.9 & 1.8 \\
\hline US & 7.0 & 8.0 & 6.8 & 2.9 & 3.7 & 1.8 \\
\hline Uruguay & 7.6 & 8.0 & 19.4 & 2.0 & 24.0 & 5.8 \\
\hline Venezuela & 4.9 & & 53.4 & 2.2 & 82.0 & 6.5 \\
\hline Zambia & 10.3 & 8.5 & 26.6 & 2.1 & 15.2 & 3.8 \\
\hline
\end{tabular}

FS size is the size of the financial sector as measured by its value added share in GDP (in \%). FS growth is financial sector growth over 1980-2007 as measured by the growth of its value added. SD (FS growth) is an indicator of volatility. It is the standard deviation of financial sector growth over the period 1980-2007. 
Table 2 Descriptive statistics for cross-sectional data

Panel A Summary statistics for cross-sectional data

\begin{tabular}{lllllll}
\hline & Growth & Volatility & Credit to GDP (\%) & Intermediation & Non-intermediation & Size \\
Mean & 1.73 & 3.46 & 46.39 & -1.12 & 0.05 & 5.04 \\
Std. Dev. & 1.42 & 1.63 & 34.76 & 0.78 & 2.72 & 3.08 \\
Min & -2.54 & 1.11 & 6.58 & -2.81 & -3.13 & 0.79 \\
Max & 5.27 & 7.30 & 147.88 & 0.38 & 16.08 & 22.76 \\
Obs & 77 & 77 & 77 & 77 & 77 & 77 \\
\hline
\end{tabular}

Panel B Pairwise correlations for cross-sectional data

\begin{tabular}{lllll}
\hline & Growth & Volatility & Intermediation & Non-intermediation \\
Growth & 1 & & & \\
Volatility & -0.18 & 1 & & \\
Intermediation & $0.35^{* * *}$ & $-0.54^{* * *}$ & 1 & 1 \\
Non-intermediation & 0.15 & -0.04 & 0.10 & $0.89^{* * *}$ \\
Size & $0.30^{* * *}$ & $-0.26^{* *}$ & $0.51^{* * *}$ & \\
\hline
\end{tabular}

Growth is the average growth rate of real GDP in \% over the period 1980-2007. The annual growth rate is calculated as the annual difference in the logarithm of real GDP per capita. Volatility is the standard deviation of the growth rate for 1980-2007. Credit to GDP are claims on the domestic private sector by banks as a \% of GDP averaged over 1980-2007. Intermediation is the log of claims on the domestic private sector by banks to GDP averaged over 1980-2007. Non-intermediation is the average of the residuals from a regression of size on intermediation. Size is the average value added share of the financial sector in GDP. 
Table 3 Descriptive statistics for panel data (5-year windows)

Panel A Summary statistics for panel data

\begin{tabular}{lllllll}
\hline & Growth & Volatility & Credit to GDP (\%) & Intermediation & Non-intermediation & Size \\
Mean & 2.42 & 2.15 & 50.73 & -1.03 & 0.11 & 5.17 \\
Std. Dev. & 2.16 & 1.77 & 41.24 & 0.87 & 3.12 & 3.33 \\
Min & -5.15 & 0.12 & 3.35 & -3.40 & -3.51 & 0.68 \\
Max & 10.91 & 10.61 & 233.56 & 0.84 & 22.90 & 29.71 \\
Obs & 280 & 280 & 280 & 280 & 280 & 280 \\
\hline
\end{tabular}

Panel B Pairwise correlations for panel data

\begin{tabular}{lllll}
\hline & Growth & Volatility & Intermediation & Non-intermediation \\
Growth & 1 & & & \\
Volatility & $-0.29^{* * *}$ & 1 & & \\
Intermediation & 0.06 & $-0.33^{* * *}$ & 1 & 1 \\
Non-intermediation & -0.01 & $0.14^{*}$ & 0 & $0.89^{* * *}$ \\
Size & 0.03 & -0.02 & $0.42^{* * *}$ & \\
\hline
\end{tabular}

Growth is the growth rate of real GDP averaged over non-overlapping 5-year windows for the period 1980-2007. The annual growth rate is calculated as the annual difference in the logarithm of real GDP per capita. Volatility is the standard deviation of the growth rate for the 5-year periods. Credit to GDP are claims on the domestic private sector by banks as a \% of GDP. Intermediation is the log of claims on the domestic private sector by banks to GDP. Non-intermediation is the average of the residuals from a regression of size on intermediation. Size is the average value added share of the financial sector in GDP. All financial sector variables are averaged over non-overlapping 5-year periods. 
Figure 1 Evolution of size and intermediation in the UK

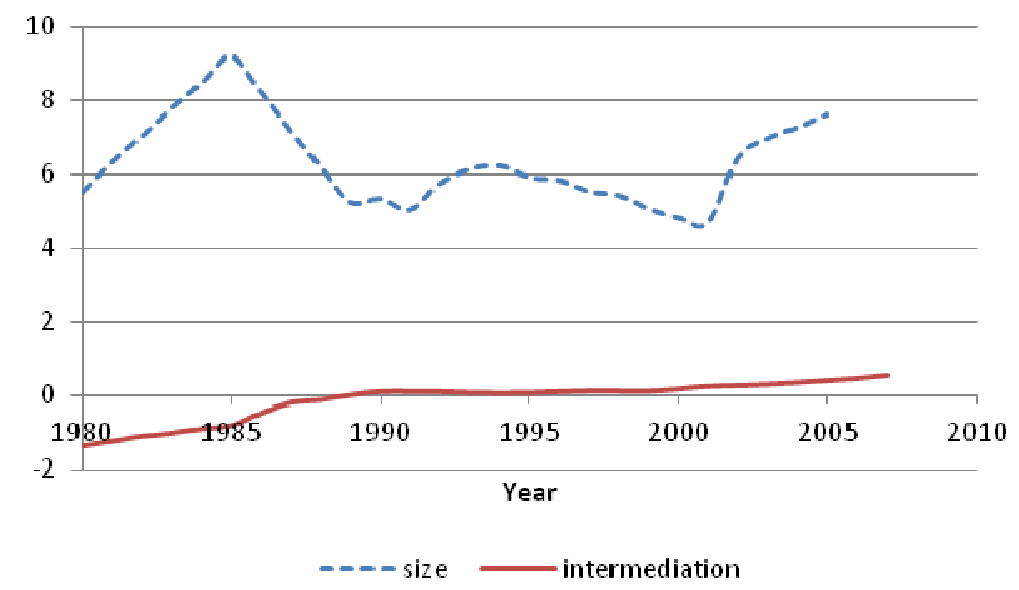

Figure 2 Evolution of size and intermediation in Turkey

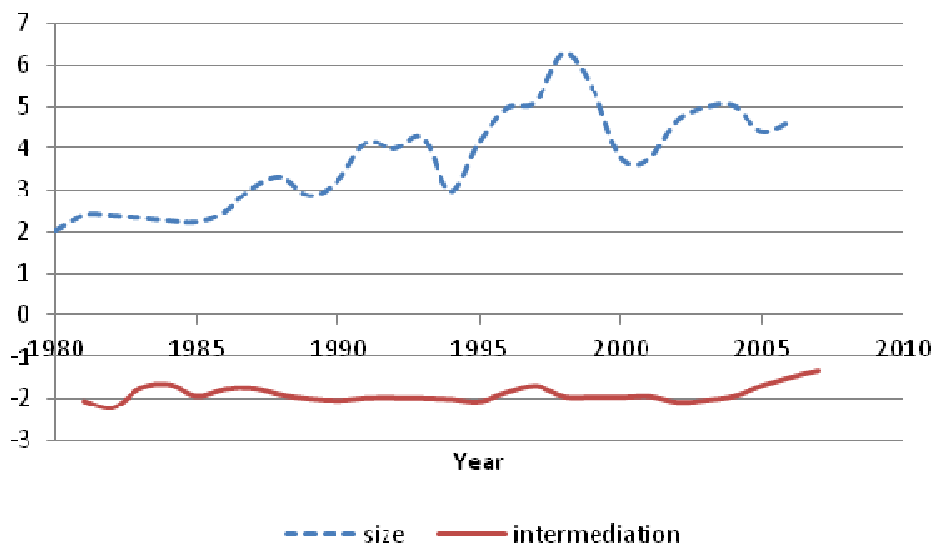

Figure 3 Evolution of size and intermediation in Mauritius

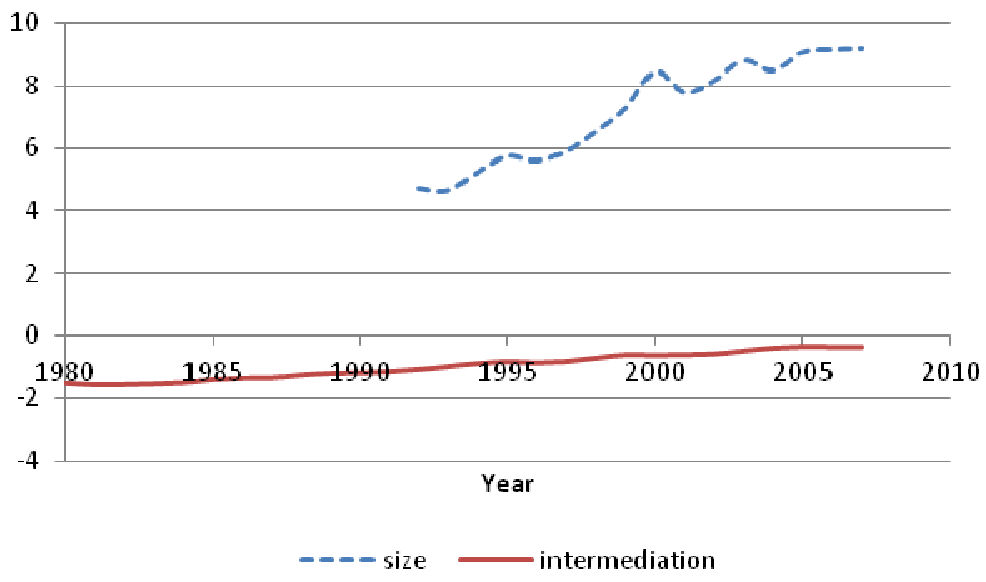


Table 4 The relationship between intermediation, growth and volatility

Panel A Cross-section

\begin{tabular}{|c|c|c|c|c|c|c|}
\hline & Growth & Growth & Growth & Volatility & Volatility & Volatility \\
\hline Intermediation & $\begin{array}{l}0.810 * * * \\
(0.286)\end{array}$ & $\begin{array}{l}0.736 * * \\
(0.282)\end{array}$ & $\begin{array}{l}0.858^{* * *} \\
(0.270)\end{array}$ & $\begin{array}{l}-0.869 * * * \\
(0.305)\end{array}$ & $\begin{array}{l}-1.215^{* * *} \\
(0.305)\end{array}$ & $\begin{array}{l}-1.021 * * * \\
(0.292)\end{array}$ \\
\hline Education & $\begin{array}{l}0.275^{* * *} \\
(0.0918)\end{array}$ & $\begin{array}{l}0.246^{* *} \\
(0.0943)\end{array}$ & $\begin{array}{l}0.285 * * * \\
(0.0913)\end{array}$ & $\begin{array}{l}0.108 \\
(0.0978)\end{array}$ & $\begin{array}{l}0.0436 \\
(0.102)\end{array}$ & $\begin{array}{l}0.106 \\
(0.0985)\end{array}$ \\
\hline Initial GDP & $\begin{array}{l}-0.577^{* * *} \\
(0.215)\end{array}$ & $\begin{array}{l}-0.502^{* *} \\
(0.221)\end{array}$ & $\begin{array}{l}-0.571^{* * *} \\
(0.209)\end{array}$ & $\begin{array}{l}-0.307 \\
(0.229)\end{array}$ & $\begin{array}{l}-0.0691 \\
(0.239)\end{array}$ & $\begin{array}{l}-0.167 \\
(0.226)\end{array}$ \\
\hline Inflation & $\begin{array}{l}-0.000780 \\
(0.00247)\end{array}$ & & & $\begin{array}{l}0.00507^{*} \\
(0.00263)\end{array}$ & & \\
\hline Openness & & $\begin{array}{l}0.00340 \\
(0.00288)\end{array}$ & & & $\begin{array}{l}0.00521 * \\
(0.00311)\end{array}$ & \\
\hline Gov.consumption & & & $\begin{array}{l}-0.0299 \\
(0.0326)\end{array}$ & & & $\begin{array}{l}-0.0572 \\
(0.0352)\end{array}$ \\
\hline Constant & $\begin{array}{l}5.391 * * * \\
(1.545)\end{array}$ & $\begin{array}{l}4.610^{* * *} \\
(1.669)\end{array}$ & $\begin{array}{l}5.771 * * * \\
(1.519)\end{array}$ & $\begin{array}{l}4.069 * * \\
(1.646)\end{array}$ & $\begin{array}{l}1.932 \\
(1.806)\end{array}$ & $\begin{array}{l}3.812^{* *} \\
(1.639)\end{array}$ \\
\hline Observations & 77 & 77 & 77 & 77 & 77 & 77 \\
\hline Adj. $R^{2}$ & 0.191 & 0.205 & 0.199 & 0.300 & 0.292 & 0.290 \\
\hline
\end{tabular}

Standard errors in parentheses.

Panel B Panel data (5-year windows)

\begin{tabular}{|c|c|c|c|c|c|c|}
\hline & Growth & Growth & Growth & Volatility & Volatility & Volatility \\
\hline Intermediation & $\begin{array}{l}0.173 \\
(0.239)\end{array}$ & $\begin{array}{l}0.102 \\
(0.265)\end{array}$ & $\begin{array}{l}0.238 \\
(0.236)\end{array}$ & $\begin{array}{l}-0.774^{* * *} \\
(0.257)\end{array}$ & $\begin{array}{l}-0.804^{* * *} \\
(0.259)\end{array}$ & $\begin{array}{l}-0.807 * * * \\
(0.252)\end{array}$ \\
\hline Education & $\begin{array}{l}0.295^{* * *} \\
(0.109)\end{array}$ & $\begin{array}{l}0.271^{* *} \\
(0.108)\end{array}$ & $\begin{array}{l}0.319 * * * \\
(0.106)\end{array}$ & $\begin{array}{l}-0.0837 \\
(0.0656)\end{array}$ & $\begin{array}{l}-0.0952 \\
(0.0698)\end{array}$ & $\begin{array}{l}-0.0959 \\
(0.0646)\end{array}$ \\
\hline Initial GDP & $\begin{array}{l}-0.468^{* *} \\
(0.203)\end{array}$ & $\begin{array}{l}-0.397^{*} \\
(0.211)\end{array}$ & $\begin{array}{l}-0.407^{*} \\
(0.213)\end{array}$ & $\begin{array}{l}0.232 \\
(0.169)\end{array}$ & $\begin{array}{l}0.255 \\
(0.182)\end{array}$ & $\begin{array}{l}0.291^{*} \\
(0.173)\end{array}$ \\
\hline Inflation & $\begin{array}{l}-0.00183 \\
(0.00113)\end{array}$ & & & $\begin{array}{l}0.00241^{*} \\
(0.00139)\end{array}$ & & \\
\hline Openness & & $\begin{array}{l}0.00483^{* *} \\
(0.00224)\end{array}$ & & & $\begin{array}{l}-0.000573 \\
(0.00231)\end{array}$ & \\
\hline Govconsumption & & & $\begin{array}{l}-0.0756^{* *} \\
(0.0302)\end{array}$ & & & $\begin{array}{l}-0.0216 \\
(0.0227)\end{array}$ \\
\hline Constant & $\begin{array}{l}4.352^{* * *} \\
(1.403)\end{array}$ & $\begin{array}{l}3.434 * * \\
(1.567)\end{array}$ & $\begin{array}{l}4.886 * * * \\
(1.349)\end{array}$ & $\begin{array}{l}0.00512 \\
(1.342)\end{array}$ & $\begin{array}{l}-0.0384 \\
(1.463)\end{array}$ & $\begin{array}{l}-0.0462 \\
(1.343)\end{array}$ \\
\hline Observations & 280 & 280 & 280 & 280 & 280 & 280 \\
\hline Adj. $R^{2}$ & 0.056 & 0.064 & 0.076 & 0.129 & 0.109 & 0.112 \\
\hline
\end{tabular}

Standard errors in parentheses. Standard errors are clustered at the country-level. 
Table 5 The relationship between size, growth and volatility

Panel A Cross-section

\begin{tabular}{|c|c|c|c|c|c|c|}
\hline & Growth & Growth & Growth & Volatility & Volatility & Volatility \\
\hline \multirow[t]{2}{*}{ Size } & $0.128^{* *}$ & $0.102 *$ & $0.129 * *$ & -0.0532 & -0.0942 & -0.0632 \\
\hline & $(0.0524)$ & $(0.0602)$ & (0.0528) & (0.0578) & (0.0693) & (0.0596) \\
\hline \multirow[t]{2}{*}{ Education } & $0.270 * * *$ & $0.250^{* *}$ & $0.284 * * *$ & 0.117 & 0.0573 & 0.111 \\
\hline & (0.0929) & (0.0977) & (0.0937) & (0.103) & $(0.112)$ & $(0.106)$ \\
\hline \multirow[t]{2}{*}{ Initial GDP } & $-0.364^{*}$ & -0.312 & $-0.363^{*}$ & $-0.611^{* * *}$ & $-0.479 * *$ & $-0.498 * *$ \\
\hline & $(0.189)$ & $(0.203)$ & (0.193) & $(0.209)$ & $(0.234)$ & $(0.218)$ \\
\hline \multirow[t]{2}{*}{ Inflation } & -0.00281 & & & $0.00739 * * *$ & & \\
\hline & (0.00237) & & & $(0.00262)$ & & \\
\hline \multirow[t]{2}{*}{ Openness } & & 0.00305 & & & 0.00384 & \\
\hline & & $(0.00321)$ & & & $(0.00370)$ & \\
\hline \multirow[t]{2}{*}{ Govconsumption } & & & -0.0187 & & & $-0.0683^{*}$ \\
\hline & & & (0.0334) & & & (0.0377) \\
\hline \multirow[t]{2}{*}{ Constant } & $2.248 * *$ & 1.771 & $2.353^{* *}$ & $7.582 * * *$ & $7.012 * * *$ & $8.014 * * *$ \\
\hline & $(1.008)$ & $(1.126)$ & $(1.036)$ & $(1.113)$ & $(1.296)$ & (1.169) \\
\hline Observations & 77 & 77 & 77 & 77 & 77 & 77 \\
\hline Adj. $R^{2}$ & 0.169 & 0.163 & 0.157 & 0.230 & 0.157 & 0.182 \\
\hline
\end{tabular}

Standard errors in parentheses.

Panel B Panel data (5-year windows)

\begin{tabular}{|c|c|c|c|c|c|c|}
\hline & Growth & Growth & Growth & Volatility & Volatility & Volatility \\
\hline \multirow[t]{2}{*}{ Size } & 0.0370 & -0.0168 & 0.0183 & 0.0138 & 0.0574 & 0.0253 \\
\hline & $(0.0472)$ & $(0.0594)$ & $(0.0504)$ & $(0.0359)$ & $(0.0395)$ & $(0.0328)$ \\
\hline \multirow[t]{2}{*}{ Education } & $0.297 * * *$ & $0.264^{* *}$ & $0.319 * * *$ & -0.0737 & -0.0590 & -0.0858 \\
\hline & (0.109) & $(0.112)$ & $(0.106)$ & $(0.0756)$ & $(0.0836)$ & $(0.0744)$ \\
\hline \multirow[t]{2}{*}{ Initial GDP } & $-0.431^{* *}$ & -0.330 & -0.329 & -0.112 & -0.178 & -0.0693 \\
\hline & (0.189) & $(0.214)$ & $(0.209)$ & (0.144) & (0.169) & (0.151) \\
\hline \multirow[t]{2}{*}{ Inflation } & $-0.00209 *$ & & & 0.00280 & & \\
\hline & $(0.00117)$ & & & $(0.00179)$ & & \\
\hline \multirow[t]{2}{*}{ Openness } & & $0.00543 * *$ & & & -0.00368 & \\
\hline & & $(0.00260)$ & & & $(0.00247)$ & \\
\hline \multirow[t]{2}{*}{ Govconsumption } & & & $-0.0731 * *$ & & & -0.0262 \\
\hline & & & (0.0299) & & & $(0.0247)$ \\
\hline \multirow[t]{2}{*}{ Constant } & $3.671^{* * *}$ & $2.869 * *$ & $3.860 * * *$ & $3.476^{* * *}$ & $4.047 * * *$ & $3.616^{* * *}$ \\
\hline & (0.993) & $(1.173)$ & $(0.940)$ & $(0.705)$ & $(0.926)$ & $(0.731)$ \\
\hline Observations & 280 & 280 & 280 & 280 & 280 & 280 \\
\hline Adj. $R^{2}$ & 0.056 & 0.064 & 0.072 & 0.059 & 0.044 & 0.036 \\
\hline
\end{tabular}

Standard errors in parentheses. Standard errors are clustered at the country-level. 
Table 6 The relationship between size, intermediation, growth and volatility

Panel A Cross-section

\begin{tabular}{lllllll} 
& \multicolumn{1}{c}{ Growth } & \multicolumn{1}{c}{ Growth } & \multicolumn{1}{c}{ Growth } & \multicolumn{1}{c}{ Volatility } & \multicolumn{1}{c}{ Volatility } & \multicolumn{1}{c}{ Volatility } \\
\hline Size & 0.0857 & 0.0682 & 0.0803 & 0.00511 & -0.0330 & 0.00834 \\
& $(0.0550)$ & $(0.0605)$ & $(0.0548)$ & $(0.0597)$ & $(0.0659)$ & $(0.0600)$ \\
Intermediation & $0.637^{* *}$ & $0.654^{* *}$ & $0.705^{* *}$ & $-0.880^{* * *}$ & $-1.175^{* * *}$ & $-1.037^{* * *}$ \\
& $(0.304)$ & $(0.291)$ & $(0.288)$ & $(0.330)$ & $(0.317)$ & $(0.315)$ \\
Education & $0.277^{* * *}$ & $0.263^{* * *}$ & $0.287^{* * *}$ & 0.108 & 0.0357 & 0.106 \\
& $(0.0909)$ & $(0.0952)$ & $(0.0906)$ & $(0.0985)$ & $(0.104)$ & $(0.0992)$ \\
Initial GDP & $-0.584^{* * *}$ & $-0.553^{* *}$ & $-0.587^{* * *}$ & -0.308 & -0.0442 & -0.169 \\
& $(0.213)$ & $(0.225)$ & $(0.208)$ & $(0.230)$ & $(0.245)$ & $(0.228)$ \\
Inflation & -0.00112 & & & $0.00505^{*}$ & & \\
\multirow{5}{*}{ Openness } & $(0.00245)$ & & & $(0.00266)$ & & \\
& & 0.00188 & & & $0.00594^{*}$ & \\
Govconsumption & & $(0.00317)$ & & & $(0.00345)$ & \\
& & & -0.0265 & & & -0.0569 \\
Constant & $4.816^{* * *}$ & $4.594^{* * *}$ & $(0.0324)$ & & & $(0.0355)$ \\
& $(1.573)$ & $(1.666)$ & $(1.549)$ & $(1.706)$ & $(1.816)$ & $(1.696)$ \\
Observations & 77 & 77 & 77 & 77 & 77 & 77 \\
Adj. $R^{2}$ & 0.206 & 0.208 & 0.211 & 0.290 & 0.284 & 0.280 \\
\hline
\end{tabular}

Standard errors in parentheses.

Panel B Panel data (5-year windows)

\begin{tabular}{lllllll} 
& \multicolumn{1}{c}{ Growth } & \multicolumn{1}{c}{ Growth } & \multicolumn{1}{c}{ Growth } & \multicolumn{1}{c}{ Volatility } & Volatility & \multicolumn{1}{c}{ Volatility } \\
\hline Size & 0.0302 & -0.0209 & 0.00736 & $0.0567^{* *}$ & $0.0871^{* * *}$ & $0.0676^{* *}$ \\
& $(0.0520)$ & $(0.0622)$ & $(0.0551)$ & $(0.0249)$ & $(0.0321)$ & $(0.0259)$ \\
Intermediation & 0.134 & 0.118 & 0.229 & $-0.847^{* * *}$ & $-0.870^{* * *}$ & $-0.889^{* * *}$ \\
& $(0.260)$ & $(0.276)$ & $(0.253)$ & $(0.258)$ & $(0.261)$ & $(0.254)$ \\
Education & $0.298^{* * *}$ & $0.265^{* *}$ & $0.320^{* * *}$ & -0.0781 & -0.0709 & -0.0876 \\
& $(0.109)$ & $(0.113)$ & $(0.107)$ & $(0.0662)$ & $(0.0728)$ & $(0.0655)$ \\
Initial GDP & $-0.482^{* *}$ & -0.378 & $-0.412^{*}$ & 0.206 & 0.173 & 0.251 \\
& $(0.205)$ & $(0.230)$ & $(0.218)$ & $(0.171)$ & $(0.188)$ & $(0.176)$ \\
Inflation & $-0.00198^{*}$ & & & 0.00212 & & \\
& $(0.00112)$ & & & $(0.00139)$ & & \\
Openness & & $0.00525^{*}$ & & & -0.00232 & \\
& & $(0.00266)$ & & & $(0.00255)$ & \\
Govconsumption & & & $-0.0752^{* *}$ & & & -0.0179 \\
& & & $(0.0310)$ & & & $(0.0223)$ \\
Constant & $4.252^{* * *}$ & $3.405^{* *}$ & $4.862^{* * *}$ & -0.183 & 0.0826 & -0.266 \\
& $(1.405)$ & $(1.594)$ & $(1.363)$ & $(1.338)$ & $(1.460)$ & $(1.335)$ \\
Observations & 280 & 280 & 280 & 280 & 280 & 280 \\
Adj. $\mathrm{R}^{2}$ & 0.054 & 0.061 & 0.072 & 0.135 & 0.124 & 0.122 \\
\hline
\end{tabular}

Standard errors in parentheses. Standard errors are clustered at the country-level. 
Table 7 Cross-sectional and panel data evidence for the period 1995-2007

Panel A Cross-section

\begin{tabular}{lllllll}
\hline & Growth & Growth & Growth & Volatility & Volatility & Volatility \\
\hline Size & 0.0300 & 0.0144 & 0.0269 & 0.0684 & 0.0598 & 0.0570 \\
& $(0.0502)$ & $(0.0565)$ & $(0.0507)$ & $(0.0496)$ & $(0.0597)$ & $(0.0518)$ \\
Intermediation & 0.0358 & -0.0314 & 0.0109 & $-0.559 *$ & $-0.859 * *$ & $-0.771^{* * *}$ \\
& $(0.285)$ & $(0.274)$ & $(0.273)$ & $(0.282)$ & $(0.290)$ & $(0.279)$ \\
Observations & 77 & 77 & 77 & 77 & 77 & 77 \\
Adj. $\mathrm{R}^{2}$ & 0.111 & 0.114 & 0.112 & 0.219 & 0.111 & 0.165 \\
\hline
\end{tabular}

Panel B Panel data (5-year averages)

\begin{tabular}{lllllll}
\hline Size & 0.0183 & -0.0164 & 0.00821 & $0.0668^{*}$ & $0.0911^{* *}$ & $0.0668^{*}$ \\
& $(0.0427)$ & $(0.0518)$ & $(0.0447)$ & $(0.0344)$ & $(0.0431)$ & $(0.0353)$ \\
Intermediation & -0.196 & -0.0812 & -0.0168 & $-0.612^{*}$ & $-0.767^{* *}$ & $-0.765^{* *}$ \\
& $(0.226)$ & $(0.251)$ & $(0.238)$ & $(0.309)$ & $(0.317)$ & $(0.309)$ \\
Observations & 197 & 197 & 197 & 197 & 197 & 197 \\
Adj. $\mathrm{R}^{2}$ & 0.107 & 0.075 & 0.071 & 0.158 & 0.086 & 0.089 \\
\hline Control: inflation & yes & no & no & yes & no & No \\
Control: openness & no & yes & no & no & yes & No \\
Control: govconsumption & no & no & yes & no & no & Yes \\
\hline
\end{tabular}

Note: The regression coefficients for the control variables are not shown. In addition to the policy variables (inflation, openness and government consumption) we include the beginning-of-period real GDP per capita and schooling as controls. Standard errors are in parentheses. Standard errors are clustered at the country-level in panel B. 
Table 8 Panel data evidence for the period 1980-2007 by income group

Panel A High income countries

\begin{tabular}{lllllll} 
& Growth & Growth & Growth & Volatility & Volatility & Volatility \\
\hline Size & $0.0971^{* *}$ & 0.0354 & 0.0630 & $0.0718^{* * *}$ & $0.0598^{* * *}$ & $0.0680^{* * *}$ \\
& $(0.0398)$ & $(0.0473)$ & $(0.0573)$ & $(0.0132)$ & $(0.0209)$ & $(0.0130)$ \\
Intermediation & -0.218 & -0.0618 & -0.0165 & -0.0312 & -0.198 & -0.183 \\
& $(0.300)$ & $(0.291)$ & $(0.323)$ & $(0.174)$ & $(0.186)$ & $(0.222)$ \\
Observations & 108 & 108 & 108 & 108 & 108 & 108 \\
Adj. $\mathrm{R}^{2}$ & 0.295 & 0.306 & 0.270 & 0.072 & 0.072 & 0.064 \\
\hline
\end{tabular}

Panel B Low income countries

\begin{tabular}{lllllll}
\hline Size & -0.0727 & -0.136 & -0.0880 & 0.0144 & 0.0902 & 0.0462 \\
& $(0.0962)$ & $(0.111)$ & $(0.0939)$ & $(0.0670)$ & $(0.0692)$ & $(0.0643)$ \\
Intermediation & 0.363 & 0.384 & 0.441 & $-0.851^{* * *}$ & $-0.859^{* * *}$ & $-0.926^{* * *}$ \\
& $(0.335)$ & $(0.345)$ & $(0.321)$ & $(0.302)$ & $(0.302)$ & $(0.304)$ \\
Observations & 172 & 172 & 172 & 172 & 172 & 172 \\
Adj. $\mathrm{R}^{2}$ & 0.076 & 0.076 & 0.078 & 0.095 & 0.105 & 0.083 \\
\hline Control: inflation & yes & no & no & yes & no & no \\
Control: openness & no & yes & no & no & yes & no \\
Control: govconsumption & no & no & yes & no & no & yes \\
\hline
\end{tabular}

Note: The regression coefficients for the control variables are not shown. In addition to the policy variables (inflation, openness and government consumption) we include the beginning-of-period real GDP p.c. and schooling as controls. Standard errors are in parentheses. Standard errors are clustered at the country-level. 
Table 9 Summary of results from KLEMS panel data for the period 1995-2007

\begin{tabular}{|c|c|c|c|c|c|c|}
\hline & Growth & Growth & Growth & Volatility & Volatility & Volatility \\
\hline Size & $0.1762^{\star \star \star}$ & $0.109^{\star}$ & $0.1631^{\star \star \star}$ & $0.0661^{* \star *}$ & $0.0906^{\star *}$ & $0.0696^{\star * *}$ \\
\hline (value added share) & $(0.032)$ & $(0.057)$ & $(0.037)$ & $(0.017)$ & $(0.039)$ & $(0.014)$. \\
\hline \multirow[t]{2}{*}{ Intermediation } & -0.171 & -0.0582 & 0.0442 & -0.0785 & -0.0991 & -0.139 \\
\hline & $(0.554)$ & $(0.530)$ & $(0.564)$ & $(0.226)$ & $(0.258)$ & $(0.234)$ \\
\hline Adj. $R^{2}$ & 0.512 & 0.492 & 0.481 & 0.092 & 0.089 & 0.080 \\
\hline Size & $0.3484^{\star * \star}$ & 0.1324 & $0.2934^{\star * \star}$ & $0.1959^{\star * \star}$ & $0.2934^{\star \star}$ & $0.2107^{\star \star \star}$ \\
\hline (employment share) & $(0.069)$ & $(0.120)$ & $(0.086)$ & $(0.052)$ & $(0.115)$ & $(0.040)$ \\
\hline \multirow[t]{2}{*}{ Intermediation } & -0.0908 & -0.0721 & 0.0952 & -0.0279 & 0.0212 & -0.0641 \\
\hline & $(0.551)$ & $(0.520)$ & $(0.561)$ & $(0.216)$ & $(0.265)$ & $(0.212)$ \\
\hline Adj. $R^{2}$ & 0.489 & 0.477 & 0.458 & 0.126 & 0.145 & 0.119 \\
\hline Size & $0.3664^{* \star \star}$ & 0.1598 & $0.3119^{\star \star \star}$ & $0.1788^{\star \star \star}$ & $0.2614^{\star \star}$ & $0.1902^{\star \star \star}$ \\
\hline (share hours) & $(0.080)$ & $(0.142)$ & $(0.094)$ & $(0.048)$ & $(0.112)$ & $(0.038)$ \\
\hline \multirow[t]{2}{*}{ Intermediation } & -0.0837 & -0.0532 & 0.105 & -0.0326 & -0.00309 & -0.0776 \\
\hline & $(0.559)$ & $(0.542)$ & $(0.572)$ & $(0.220)$ & $(0.272)$ & $(0.220)$ \\
\hline Adj. $R^{2}$ & 0.494 & 0.479 & 0.462 & 0.110 & 0.119 & 0.101 \\
\hline Size & $0.1620^{\star \star \star}$ & 0.0577 & $0.1421^{\star \star}$ & $0.1032^{\star \star \star}$ & $0.1437^{\star \star}$ & $0.1122^{\star \star \star}$ \\
\hline (compensation share) & $(0.039)$ & $(0.057)$ & $(0.052)$ & $(0.035)$ & $(0.068)$ & $(0.025)$ \\
\hline \multirow[t]{2}{*}{ Intermediation } & -0.126 & -0.102 & 0.0529 & -0.0419 & -0.0277 & -0.0845 \\
\hline & $(0.560)$ & $(0.518)$ & $(0.568)$ & $(0.218)$ & $(0.265)$ & $(0.213)$ \\
\hline Adj. $R^{2}$ & 0.478 & 0.476 & 0.452 & 0.130 & 0.140 & 0.121 \\
\hline Control: inflation & yes & no & no & yes & no & no \\
\hline Control: openness & no & yes & no & no & yes & no \\
\hline Control: govconsumption & no & no & yes & no & no & yes \\
\hline Observations & 78 & 78 & 78 & 78 & 78 & 78 \\
\hline
\end{tabular}

Note: The regression coefficients for the control variables are not shown. In addition to the policy variables (inflation, openness and government consumption) we include the beginning-of-period real GDP p.c. and schooling as controls. Standard errors are in parentheses. Standard errors are clustered at the country-level. 


\section{Data sources}

\begin{tabular}{|c|c|c|}
\hline Variable & $\begin{array}{l}\text { Variable Definition } \\
{\left[\ln \left(y_{t}\right)-\ln \left(y_{t-1}\right)\right]^{*} 100 \text { where } y \text { is GDP per capita in constant local }} \\
\text { currency units }\end{array}$ & Source \\
\hline Volatility & Standard deviation of Growth & \\
\hline Size & Gross value added of the financial sector as a percentage of GDP & UNSD \\
\hline Intermediation & $\ln (\mathrm{c})$ where $\mathrm{c}$ is private credit by deposit money banks divided by GDP & World Bank \\
\hline Non-intermediation & Residual from the OLS regression of Size on Intermediation & \\
\hline Education & Average years of schooling of population aged 25 and over & Barro and Lee \\
\hline Initial GDP & log of real GDP per capita in US dollars at beginning of period & WDI \\
\hline Inflation & Growth rate of annual CPI & IFS \\
\hline Openness & Exports plus imports divided by GDP & \\
\hline Exports & Exports of goods and services in constant local currency units & WDI \\
\hline Imports & Imports of goods and services in constant local currency units & WDI \\
\hline Govconsumption & Government final consumption expenditure as a percentage of GDP & WDI \\
\hline Employment share & Employment in financial sector divided by total employment & KLEMS \\
\hline Share hours & Hours worked in financial sector divided by total hours worked & KLEMS \\
\hline Compensation share & Compensation share of employees in financial sector & KLEMS \\
\hline
\end{tabular}


Table A1 Panel data evidence for the period 1995-2007 by income group

Panel A High income countries

\begin{tabular}{lllllll} 
& Growth & Growth & Growth & Volatility & Volatility & Volatility \\
\hline Size & $0.0777^{* *}$ & 0.0180 & $0.0955^{* *}$ & $0.0750^{* * *}$ & 0.0428 & $0.0489^{* * *}$ \\
& $(0.0334)$ & $(0.0455)$ & $(0.0428)$ & $(0.0226)$ & $(0.0376)$ & $(0.0126)$ \\
Intermediation & -0.534 & -0.520 & -0.316 & 0.306 & 0.128 & 0.178 \\
& $(0.366)$ & $(0.361)$ & $(0.371)$ & $(0.272)$ & $(0.185)$ & $(0.250)$ \\
Observations & 63 & 63 & 63 & 63 & 63 & 63 \\
Adj. $\mathrm{R}^{2}$ & 0.353 & 0.376 & 0.337 & 0.061 & 0.105 & 0.097 \\
\hline
\end{tabular}

Panel B Low income countries

\begin{tabular}{lllllll}
\hline Size & -0.0241 & -0.0495 & -0.0226 & 0.0446 & 0.107 & 0.0542 \\
& $(0.0866)$ & $(0.102)$ & $(0.0895)$ & $(0.0783)$ & $(0.0916)$ & $(0.0790)$ \\
Intermediation & -0.0371 & 0.123 & 0.139 & $-0.634^{*}$ & $-0.769^{* *}$ & $-0.803^{* *}$ \\
& $(0.278)$ & $(0.309)$ & $(0.296)$ & $(0.353)$ & $(0.346)$ & $(0.346)$ \\
Observations & 134 & 134 & 134 & 134 & 134 & 134 \\
Adj. $\mathrm{R}^{2}$ & 0.107 & 0.051 & 0.053 & 0.139 & 0.092 & 0.064 \\
\hline Control: inflation & yes & No & no & yes & no & no \\
Control: openness & no & Yes & no & no & yes & no \\
Control: govconsumption & no & No & yes & no & no & yes \\
\hline
\end{tabular}

Note: The regression coefficients for the control variables are not shown. In addition to the policy variables (inflation, openness and government consumption) we include the beginning-of-period real GDP per capita and schooling as controls. Standard errors are in parentheses. Standard errors are clustered at the country-level. 
Table A2 Summary of results for KLEMS panel data for the period 1980-2007 (excluding transition countries)

\begin{tabular}{lllllll}
\hline & & & & & & \\
& Growth & Growth & Growth & Volatility & Volatility & Volatility \\
\hline Size & $0.1911^{* * *}$ & $0.1309^{* *}$ & $0.1573^{* * *}$ & $0.0881^{* * *}$ & $0.0981^{* * *}$ & $0.0799^{* * *}$ \\
(value added share) & $(0.023)$ & $(0.061)$ & $(0.033)$ & $(0.021)$ & $(0.029)$ & $(0.023)$ \\
Intermediation & -0.0564 & 0.403 & 0.330 & -0.324 & $-0.422^{* *}$ & $-0.477^{* * *}$ \\
& $(0.250)$ & $(0.336)$ & $(0.395)$ & $(0.206)$ & $(0.185)$ & $(0.163)$ \\
Adj. $\mathrm{R}^{2}$ & 0.405 & 0.272 & 0.270 & 0.183 & 0.169 & 0.173 \\
\hline Size & $0.4107^{* * *}$ & $0.2917^{* *}$ & $0.3540^{* * *}$ & $0.2366^{* * *}$ & $0.2712^{* * *}$ & $0.2260^{* * *}$ \\
(employment share) & $(0.070)$ & $(0.138)$ & $(0.084)$ & $(0.049)$ & $(0.071)$ & $(0.060)$ \\
Intermediation & 0.162 & 0.529 & 0.495 & -0.220 & -0.305 & $-0.363^{* *}$ \\
Adj. $\mathrm{R}^{2}$ & 0.392 & 0.278 & 0.271 & 0.227 & 0.212 & 0.210 \\
\hline Size & $0.3973^{* * *}$ & $0.2574^{*}$ & $0.3317^{* * *}$ & $0.2272^{* * *}$ & $0.2541^{* * *}$ & $0.2112^{* * *}$ \\
(share hours) & $(0.082)$ & $(0.137)$ & $(0.087)$ & $(0.056)$ & $(0.078)$ & $(0.067)$ \\
Intermediation & 0.179 & 0.527 & 0.486 & -0.210 & -0.301 & $-0.370^{* *}$ \\
& $(0.266)$ & $(0.354)$ & $(0.393)$ & $(0.195)$ & $(0.203)$ & $(0.141)$ \\
Adj. $\mathrm{R}^{2}$ & 0.375 & 0.265 & 0.257 & 0.212 & 0.195 & 0.196 \\
\hline Size & $0.2120^{* * *}$ & $0.1595^{* *}$ & $0.1933^{* * *}$ & $0.1049^{* * *}$ & $0.1095^{* *}$ & $0.0963^{* *}$ \\
(compensation share) & $(0.031)$ & $(0.070)$ & $(0.039)$ & $(0.029)$ & $(0.045)$ & $(0.036)$ \\
Intermediation & 0.0364 & 0.436 & 0.416 & -0.284 & $-0.398^{*}$ & $-0.435^{* *}$ \\
& $(0.255)$ & $(0.338)$ & $(0.389)$ & $(0.200)$ & $(0.191)$ & $(0.159)$ \\
Adj. $\mathrm{R}^{2}$ & 0.395 & 0.283 & 0.274 & 0.192 & 0.172 & 0.173 \\
\hline Control: inflation & yes & no & no & yes & no & no \\
Control: openness & no & yes & no & no & yes & no \\
Control: govconsumption & no & no & yes & no & no & yes \\
Observations & 106 & 106 & 106 & 106 & 106 & 106 \\
\hline
\end{tabular}

Note: The regression coefficients for the control variables are not shown. In addition to the policy variables (inflation, openness and government consumption) we include the beginning-of-period real GDP per capita and schooling as controls. Standard errors are in parentheses. Standard errors are clustered at the country-level. 